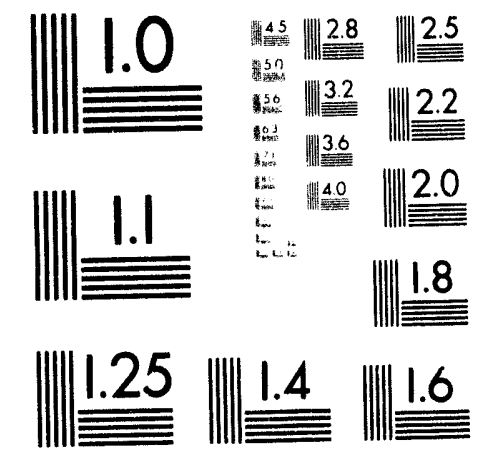



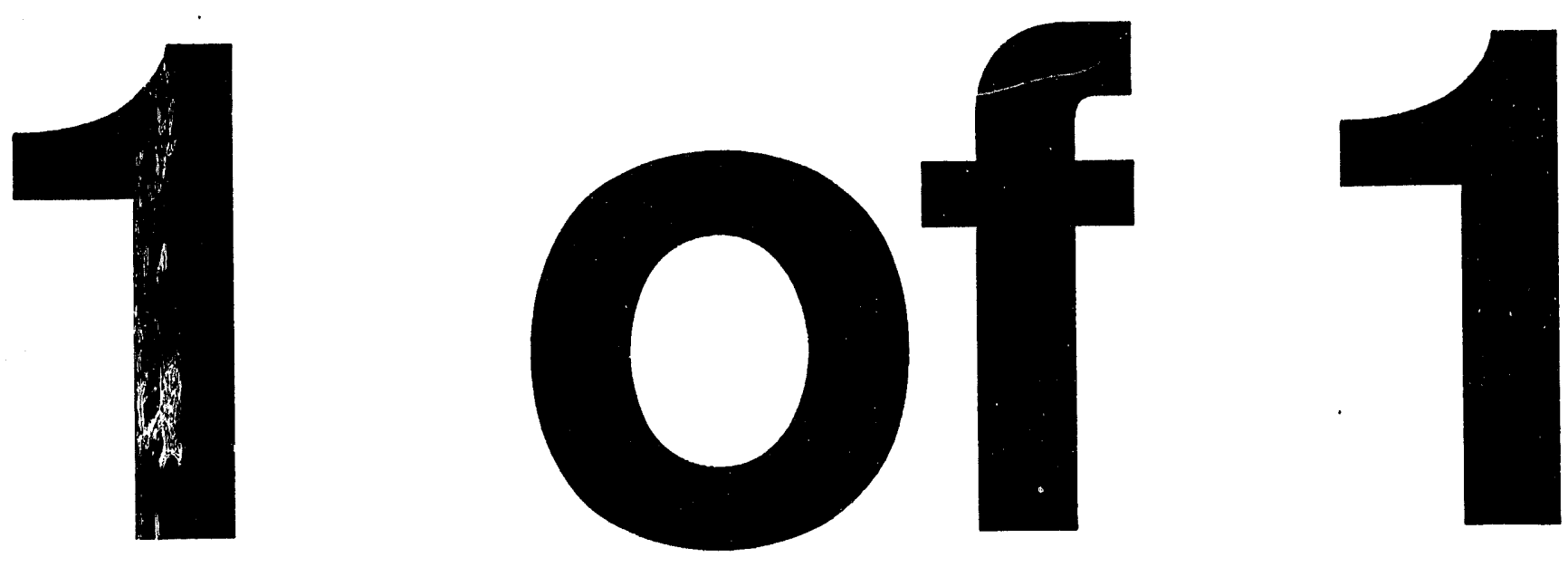
ES/ER/TM-89

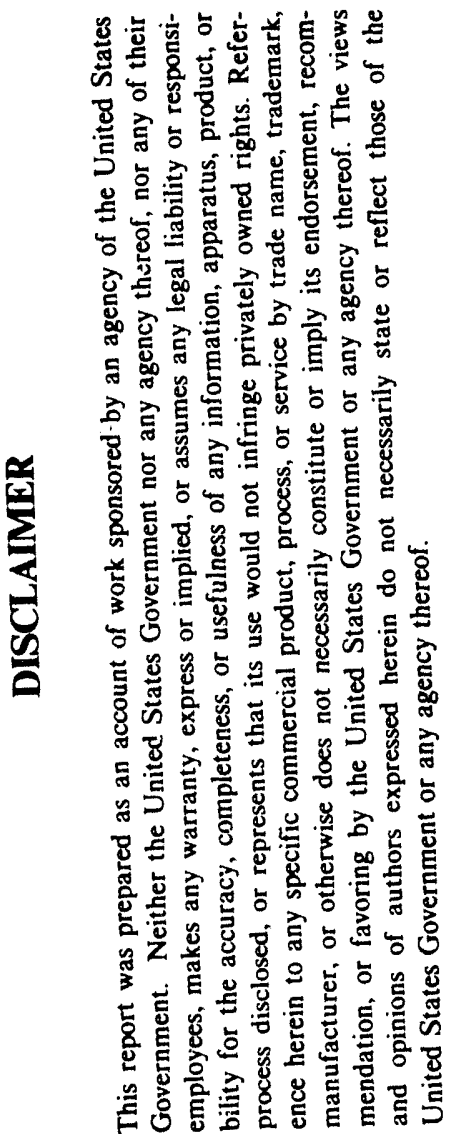

\section{Environmental Restoration Program Pollution Prevention Checklist Guide for the Feasibility Study Project Phase}

Environmental Restoration Division

P.O. Box 2003

Oak Ridge, Tennessee 37831-7298

Date Issued-September 1993

Prepared for

U.S. Department of Energy

Office of Environmental Restoration and Waste Management under budget and reporting code EW 20

MARTIN MARIETTA ENERGY SYSTEMS, INC.

managing the

Oak Ridge K-25 Site

Oak Ridge Y-12 Plant

Oak Ridge National Laboratory under contract DE-AC05-84OR21400
Paducah Gaseous Diffusion Plant Portsmouth Gaseous Diffusion Plant under contract DE-AC05-76OR00001

for the

U.S. DEPARTMENT OF ENERGY 


\section{CONTENTS}

ACRONYMS $\ldots \ldots \ldots \ldots \ldots \ldots \ldots \ldots \ldots \ldots \ldots \ldots \ldots \ldots \ldots \ldots \ldots$

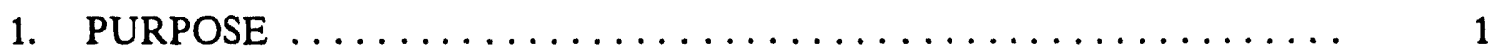

2. APPLICABILITY $\ldots \ldots \ldots \ldots \ldots \ldots \ldots \ldots \ldots \ldots \ldots \ldots \ldots$

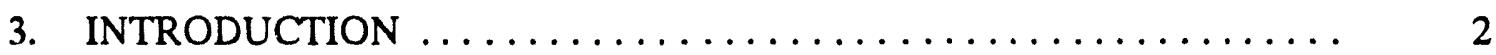

4. US: OF THIS CHECKLIST GUIDE FOR THE FS PROJECT $\ldots \ldots \ldots .3$

5. INSTRUCTIONS FOR FS PROJECT PHASE USERS

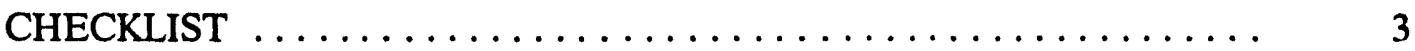

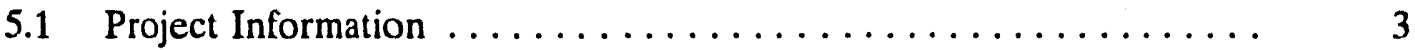

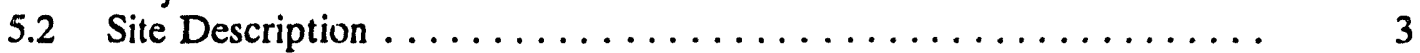

5.3 General Question Information .................. 3

5.4 FS Phase-Specific Question Information ............. 3

5.5 Waste Stream Information .................... 3

5.5.1 Summary Hazardous Constituent/Waste
Group Table $\ldots \ldots \ldots \ldots \ldots \ldots \ldots \ldots \ldots \ldots \ldots \ldots \ldots . \ldots \ldots \ldots$

5.5.2 Applicable Treatment Technology Summary ............ 18

5.5.3 Treatment Technology Evaluation Incorporation PPWM ..... 18

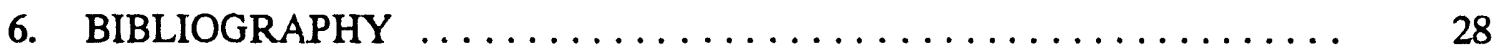

Figure 1 FS Project Phase Checklist $\ldots \ldots \ldots \ldots \ldots \ldots \ldots \ldots \ldots \ldots \ldots$

Figur: 2 Example Waste Stream Information . . . . . . . . . . . . . . 14

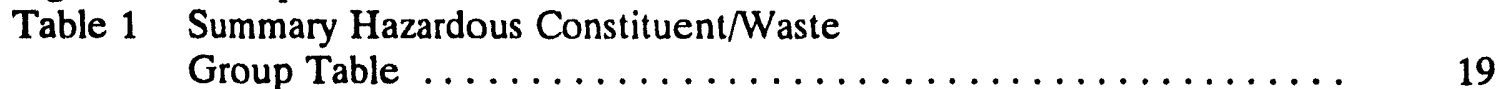

Table 2 Summary Technology Correlation

Table 3 Summary Technology Correlation

Table 4 Summary Technology Correlation

Table-Thermal Treatment ................... 26

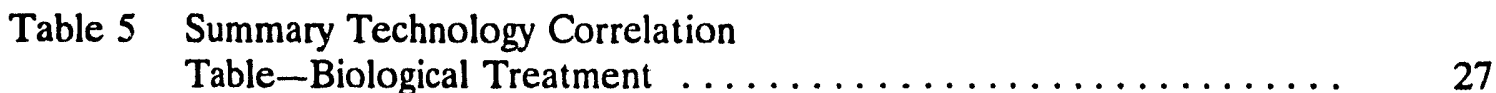




\section{ACRONYMS}

$\begin{array}{ll}\text { AOC } & \text { area of contamination } \\ \text { ATTIC } & \text { Advanced Treatment Technologies Information Center } \\ \text { CAA } & \text { Clean Air Act of } 1970 \\ \text { CERCLA } & \text { Comprehensive Environmental Response, Compensation, and Liability Act of } \\ & 1980 \\ \text { EPA } & \text { U.S. Environmental Protection Agency } \\ \text { ER } & \text { Environmental Restoration } \\ \text { FS } & \text { feasibility study } \\ \text { NPDES } & \text { National Pollution Discharge Elimination System } \\ \text { PPT } & \text { physical treatment technologies } \\ \text { PP/WM } & \text { pollution prevention/waste minimization } \\ \text { QA } & \text { quality assurance } \\ \text { RCRA } & \text { Resource Conservation and Recovery Act of } 1976 \\ \text { TCE } & \text { trichloroethylene } \\ \text { TTT } & \text { thermal treatment technologies } \\ \text { WA } & \text { waste assessment }\end{array}$ 


\section{PURPOSE}

Feasibility studies (FS) determine what remedial alternatives are presented to regulators for site cleanup. A key consideration in this process is the waste to be generated. Minimizing the volume and toxicity of this waste will ultimately contribute to the selection of the best remedial option.

The purpose of this checklist guide is to assist the user in incorporating pollution prevention/waste minimization (PP/WM) in all FS phase projects of the Environmental Restoration (ER) Program. This guide will help users document PP/WM activities for technology transfer and reporting requirements. Automated computer screens will be created from the checklist data to assist users with implementing and evaluating waste reduction. Users can then establish numerical performance measures to measure progress in planning, training, self-assessments, field implementation, documentation, and technology transfer. Cost savings result as users train and assess themselves and perform preliminary waste assessments.

\section{APPLICABILITY}

This checklist guide applies to all ER Program participants performing FS phase projects for all sources of pollution including air emissions, water, and solid waste. This guide is intended to serve three primary audiences:

- Site project managers and others on the project team engaged in activities focusing on or ultimately serving the process of incorporating PP/WM in the FS phase project;

- ER PP/WM specialists-for use as a general overview to help ensure that PP/WM criteria are being applied whenever possible in all FS phase projects; and

- ER Technology Development and Application specialists-for use as a tool for providing new and effective technology information to the site project managers.

Although this checklist guide may be used by a number of individuals as indicated above, it is incumbent on the ER Program to ensure that the projects select and apply technologies that not only result in the smallest quantities of waste with the least toxicity, but also minimize environmental releases during remediation. Minimizing waste generation should be considered in addition to the capital, maintenance, and operating costs to implement liabilities and any potential threat to human health and the environment. 


\section{INTRODUCTION}

ER activities differ significantly from routine production facilities. While the focus for PP/WM for production operations is often on source reduction and recycling, those techniques are not readily adaptable to ER projects. Opportunities for source reduction and recycling are limited for clean-up activities since ER inherits contaminated waste sites from previous production processes, where ongoing process operations generally do not exist. Although treatment is not a preferred alternative per the U.S. Environmental Protection Agency (EPA) hierarchy, the nature of ER activities is generally such that clean up of the site by the application of some treatment technology is often the only alternative. The fact that the waste exists cannot be changed.

The greatest impact on the minimization of waste from the standpoint of the overall ER Program would be the selection of the clean-up option for remediation at a site. The FS phase will generate the remedial alternatives from which the selection of the best clean-up option will be determined. The remediation will most likely encompass the following or combinations thereof:

- contain and control,

- in-situ immobilization,

- in-situ treatment,

- ex-situ treatment and return,

- ex-situ treatment and removal, and

- no action.

The success of incorporating PP/WM in the FS phase project will be determined ultimately on how well the volume and toxicity of the waste generated is minimized. However, the evaluation of options and selection of the most appropriate treatment technology for a site (when treatment is deemed appropriate) can be a complex undertaking when the many variables and issues during the remedy selection process are considered. This guide will be useful during the process of how PP/WM is incorporated when treatment technologies are evaluated. Therefore, all efforts contributing to the selection of the best remedial option and treatment technology will effectively achieve the objectives of PP/WM. 


\section{USE OF THIS CHECKLIST GUIDE FOR THE FS PROJECT}

The document guide is organized in three sections. The first section of the checklist guide contains general questions concerning the generator's pollution prevention program. The second section of the checklist guide contains questions concerning the generator's pollution prevention program as it applies to the FS phase. The third section of the guide is more project specific and entails questions about contaminants, media, and waste streams. The generator is also asked to give their rationale on their evaluation of applicable technologies analysis and how they would incorporate pollution prevention.

\section{INSTRUCTIONS FOR FS PROJECT PHASE USERS CHECKLIST}

The following are steps used to simplify this guide.

\subsection{PROJECT INFORMATION}

Complete the project information as requested in Sect. 1 of the FS Project Phase Checklist (Fig. 1, p. 4).

\subsection{SITE DESCRIPTION}

Complete the site description as requested in Sect. 1 of the FS Project Phase Checklist (Fig. 1). Provide attachments if necessary.

\subsection{GENERAL QUESTION INFORMATION} (Fig. 1).

Complete the general questions as requested in Sect. 1 of the FS Project Phase Checklist

\subsection{FS PHASE-SPECIFIC QUESTION INFORMATION}

Complete the FS phase-specific questions as requested in Sect. 2 of the FS Project Phase Checklist (Fig. 1).

\subsection{WASTE STREAM INFORMATION}

Refer to the Example Waste Stream Information (Fig. 2, p. 14). Complete the waste stream information requested in Sect. 3 of the FS Project Phase Checklist (Fig. 1). 
SECTION 1. GENERAL QUESTION INFORMIATION

Project Name:

Phase: FS
Projecl Manager:

Project Location:

Site Description:

1. Is there a PP/WM Site Plan on site?

2. Have those that report to management been trained on:

- Site general employee radiation training?

- 24-br SARA/OSHA (HAZWOPER) with 8-hr annual refresher?

- RCRA bazardous waste generator?

- Pollution prevention and waste minimization?

3. Does the PP/WM Site Plan have the following objectives and statements of scope:

- A statement of PP/WM scope and objectives developed and distributed to all project personnel.

- A statement of PP/WM scope and objectives developed and distributed to all contractor personnel.

- A statement of PP/WM scope and objectives developed and distributed to all safety and emergency response personnel.

- Specific numerical goals for PP/WM for each project waste stream set and diatributed or displayed to all project personnel.

- Specific numerical goals for PPNWM for eacti project waste stream set and distributed or displayed to all contractor personnel.

- Spocific aumerical gaals for PPNWM for each project waste stream set and distributed or displayed to all safety and emergency personnel.

4. Have project managers or personnel initiated PP/WM site plans for projects that are scheduled to start within 180 days or less from now?

Fig. 1. FS Project Phase Chacklist. 
- PPNWM incorporated in any of the project work and waste management plans?

- A ection on PPNWM incorporated in at least of one of the project work and waste management plans?

- A section on PPNWM in all the project work and waste management plans?

- A section on PP/WM in all the project work and waste management plans. Each section discusses at least three technique - to reduce or prevent waste generation?

5. Do project managers or personnal have the following data relating to site operations and waste streams so that PP/WM opportunities can be identified:

- Supply and distribution record (i.e., chemical inventory, chain of custody, and waste drum (racking)?

- Maintenance records (i.e., inspection and preventive maintenance, repair ordera)?

- Supervision records (i.e., QA audits, noncompliance, and personnel records)?

- Required permits ar 1 records (i.e., CAA, NPDES, and RCRA monitoring, RCRA accumulations facility inventories and manifests, CERCLA reportable quantity release, sample waste analyses, and RADCON Manual Compliance)?

- PP/WM Program documentation (i.e., all work and waste management plans for projects scheduled 180 days or less from now)?

- Design information (i.e., process flow diagrams and material balances)?

- Environmental information and reporting (i.e., sample waste analyses, RCRATTennessec Annual Report, EPA Biannual Report, and Pollution Prevention Act Tri-Report)?

- Raw material site information (i.e., material safety data sheets, contractor data logs, site operating procedures, and project schedules and milestones)?

- Economic information (i.e., waste treatment, disposal, operating, maintenance, departmental, and pollution prevention implementation costs)? 
6. Have project managers or personnel had the PP/WM Program audited in the last 12 months?

Was the program audited in the following manner:

- A periodic schedule for audit of activities made?

- Audit performed by those who have direct responsibility for performing the activities being audited?

- Audit performed by those who do not bave direct responsibility for performing the activities being audited?

- Audit always reviewed by responsible management?

- Follow-up action is always taken as a result of the audit?

7. Have project managers or personnel insisted on assessment of the waste streams to reduce or prevent waste generation?

Have the following project waste assessment elements been performed:

- Review of the PP/WM operations and waste management issues and targeted work sites that should be assessed?

- Development of flow diagrams and materials balances for each targeted work site?

- Ideatification of PPNWM opportunities and projects that address those opportunities?

- Evaluation and ranking of projects into a coordinated long-range plan?

8. Do project managers or personnel have cost, echedule, and program contents specific to the PP/WM Program sctivities?

What kind of wasto accounting is performod?

- Are operating cost records kepl?

- Are treatment cost records kept?

- Are disposal cost records kept?

- Are maintenance cost records kept?

Fig. 1 (conlinucd) 
- Are life-cycle cost records kept?

- Are costs to implement pollution prevention activities kept?

- Are real-time cost savings since PP/WM Site Plan implementations kept?

9. Have project managers or personnel evaluated the PP/WM Program to the numerical goal criteria in the last 12 months?

Are the following criteria used to evaluate the PP/WM Program:

- Number of numerical goals achieved?

- Number of cost reductions achieved?

- Number of noncompliances cited?

- Number of new technologies integrated?

- Number of noncompliances corrected?

10. Do project managers or personnel keep and organize records from PP/WM activities for quality assurance purposes?

Are records from pollution prevention activities kept and organized in the following manner:

- Records fumish documentary evidence from all pollution prevention activities.

- Records are well-organized and are easy to assess?

- Records are prolected against damage, deterioratioa, or loas?

- Requirements end responsibilities for record transmittal, distribution, releation, maintenance, and dispositions are established and documented?

11. Is tochnology information available for comparison from other sites for PP/WM assessment?

- Parameters and results of a material or characierization activity?

- Impact of the project of implementing a new technology?

- Characterization activities and materials currently used?

Fig. 1 (continued) 
- Remedial characterization astivities and materials under consideration?

12. If new technology information is available from other sites, does the facility manager or personnel have a timelable, cost schedule, and possible implementation procedures on the dew technology?

13. Do facility managers or personnel implement mechanisms for quality improvement in PP/WM to preveat noncompliance?

How often does management assess the PP/WM to quality assure that it is adequate and is effoctively implemented?

Never.

No regular schedule for assessing the PP/WM Program; occasionally performed.

Regular schedule for assessing the PPNWM Program, performed every 2 years.

Regular schedule for assessing the PP/WM Program, performed every year.

Regular schedule for assessing the PP/WM Program, performed at least every 6 months.

14. Does the facility manager/personnel know who handles the waste generated?

It is not known who handles the waste.

The site waste management organization handles the waste.

The site management organization handles the waste and provides some data to meet reporting requirements.

The site waste management organization handles the waste and provides all dat to meet reporting requirements.

\section{SECTION 2. FS PHASE-SPECIFIC QUESTION DNFORMATION}

1. Is there a ER PP/WM Site Plan on site?

2. Is PP/WM currently incorporated in the treatability study documents (optional)?

Fig. 1 (continued) 
3. Is PP/WM currently incorporated in the feasibility study documents?

4. Does the ER PPNM Site Plan include specific quantitative goals for reducing the volume or toxicity of each waste stream?

5. If specific numerical goals are not included for each waste stream, is a stralegy outlined to arrive at aumerical goals?

6. Does the ER PP/WM Site Plan include programmatic goals for the evaluation of DCw technologies to reduce waste generation for FS aclivities?

7. Does the E: PP/WM Site Plan contain a budget for its waste minimization program?

8. Is there a method for tracking waste for the ER site's waste management activities from the point of generation to the poinf of dischaige or treatment, storage, or disposal?

9. Has the organization developed baseline data for the generation of waste?

10. Is there a method for accounting for waste management costs?

11. Has the organization developed guidance for applying quality assurance to waste minimization activities?

12. Does the ER PPNWM Site Plan explain how PP/WM principles are incorporated into activities involving FS?

13. Have ER PPNWM waste assessments (WAs) been conducted on the waste streams that have been generated?

14. If ER PPNWM WAs have not been conducted, are there plans to conduct WAs in this fiscal year?

15. Does the ER PP/WM site Plan identify research and development projects related to FS ectivities?

16. Does the ER PPNWM Site Plan describe technology tonnefer activities that are planoed for FS activitien?

17. Does the ER PP/WM Site Plan describe a procedure for evaluating the FS PPNWM program?

18. Does the ER PP/WM Site Plan explain how design principles that minimize waste generation are incorporated into new construction and into options that involve new or modified processes? 
SECTION 3. WASTE STREAMI NFORMATION

Site Description:

\section{WASTE GROUP DENTIFICATION SUNQMARY}

Contaminant

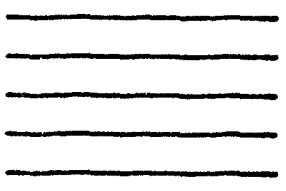

Contaminant Group

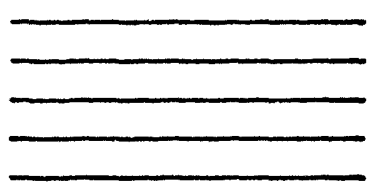

APPLICABLE TREATMENT TECHNOLOGY SUMMARY

Conceminent Group(s):

Modia Type(s):

Fig. 1 (conlinued) 


\section{Applicable Treatment Technologies:}

\section{Physical Treatments:}

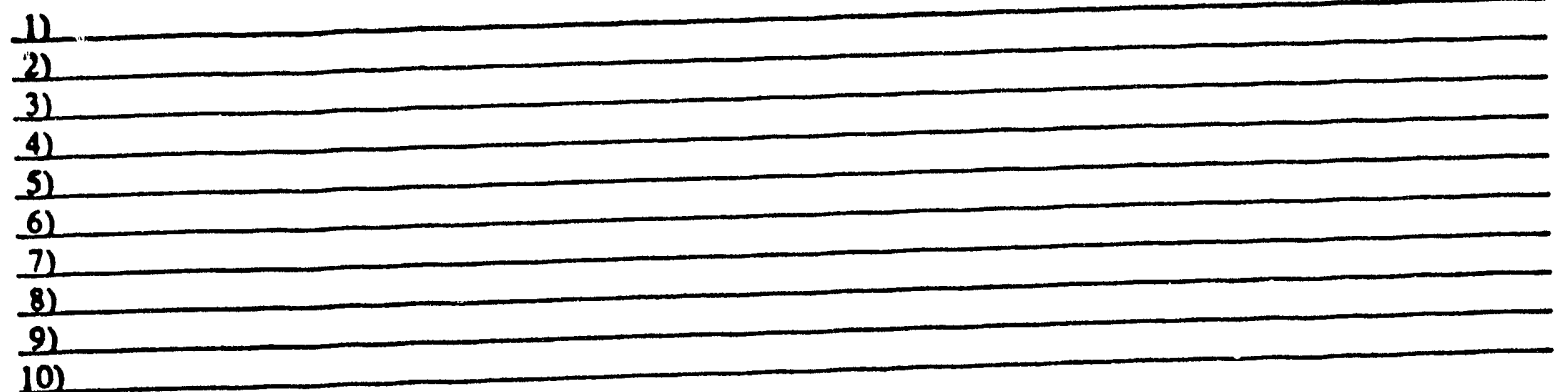

\section{Thermal Treatments:}

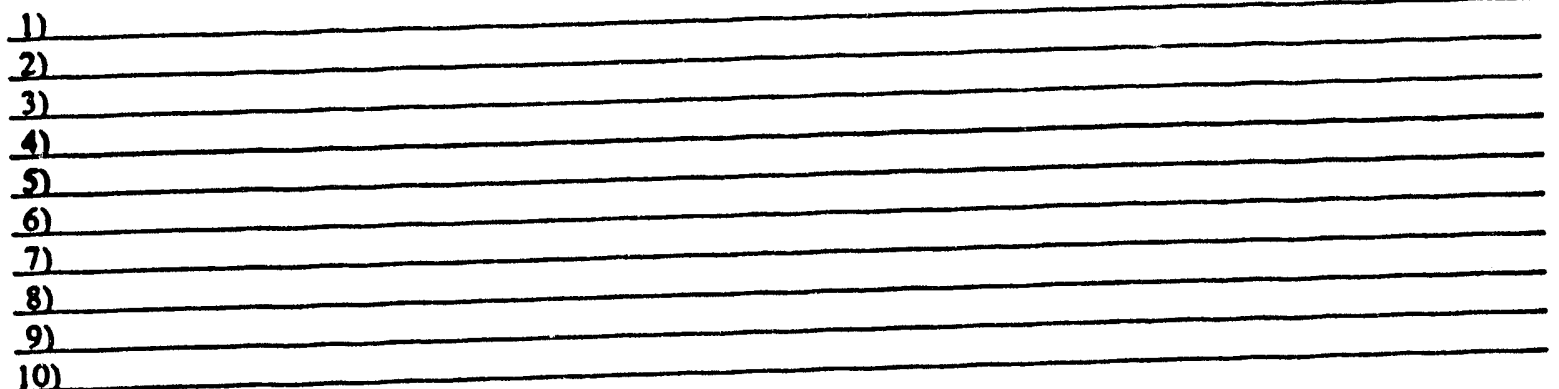

\section{Chemical Treatments:}

11

2)

3)

4)

5)

6)

$\pi$

8)

9)

10)

Fig. 1 (continued) 
Biological Treatments:

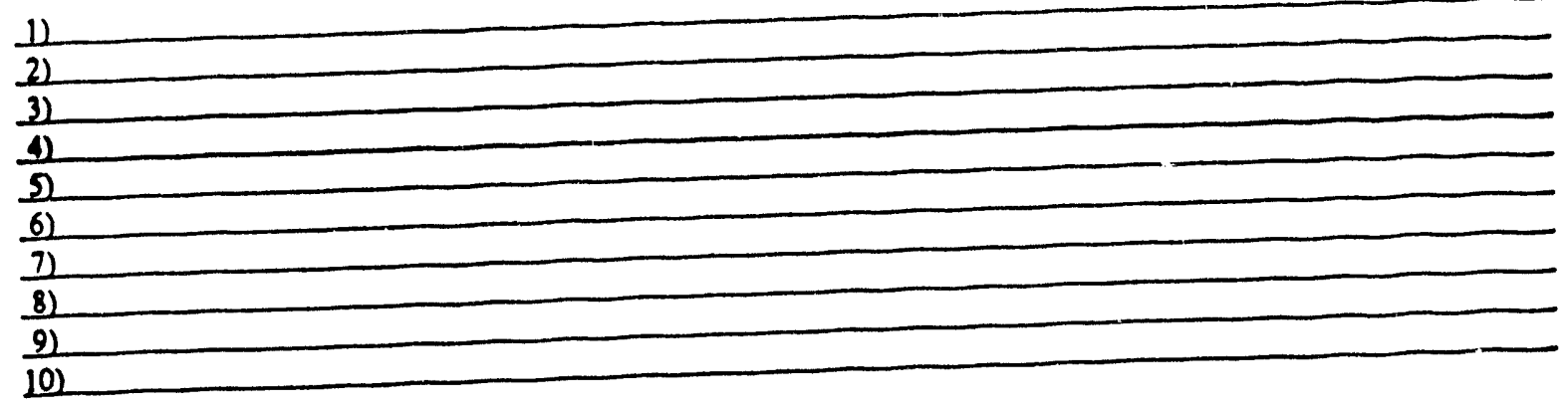

\section{TECHNOLOGY EVALUATION RATIONAL DNCORPORATDNG PP/WM}

Treatment Evaluation Rationale:

Fig. 1 (continued) 
PP/WM Rationale:

Have any applicable treatment lechnologies been identified that reduce? _ Volume — Toxicity_ Does Not
Apply

YES NC

Have any applicable treatment technologies been identified that immobilize contaminants?

Can any primary waste stream(s) be reused or recycled after treatment?

Can any primary waste stream(s) be retumed to the area of contamination (AOC) after treatment?

Can any primary waste stream(s) be exchanged for reuse after treatment?

Can any secondary waste stream(s) be reused or recycled?

Can any secondary waste stream(s) be relumed to the AOC?

Can any secondary waste stream(s) be exchanged for reuse after ireatment?

PP/WM Rational:

Fig. 1 (continuad) 
WASTE STREAM LNFOR.MIATION

Site Description: Sile with soil conlaminated with Arsenic and Trichlorocthylene (TCE). The contamination is concentraled in the lop 3 fit of soil at the site. The soil conlains a high percentage of fines, clay, and rock and a significant amount of rools. leaves, ind other decomposing material.

HAZARDOUS CONSTITUENTNWASTE GROUP IDENTIFICATION SUMMIARY

\begin{tabular}{ll}
\multicolumn{1}{c}{ Contaminant } & Contaminant Group \\
\hline Arsenic & Volatile Metal \\
\hline & \\
\hline
\end{tabular}

APPLICABLE TREATMENT TECHNOLOGY CORRELATION SUMIMARY

Contaminant Group(s): Volatile metals. Halosenated volatiles .

Modia Type(s): Solids

Fig. 2 Example Wastc Strciam Information. 
Applicable Treatment Technologies:

Physical Treatments:

1) In-Situ Steam Iniection and Vacuum Extraction

2) In-Situ Sterm Enhanced Exinaction

3) In-Situ Solidification and Stabilization

4) Chemical Treatment and Immobilization

5) Soil/Sediment Washing

6)

7)

B)

2)

10)

Thermal Treatments:

1) Thermal Gas Phase Reduction

2) Desorption and Vapor Extraction

3) Cyclone Fumace

4) Thermal Desorption

5)

6)

7)

8)

29)

10)

\section{Chemical Treatments:}

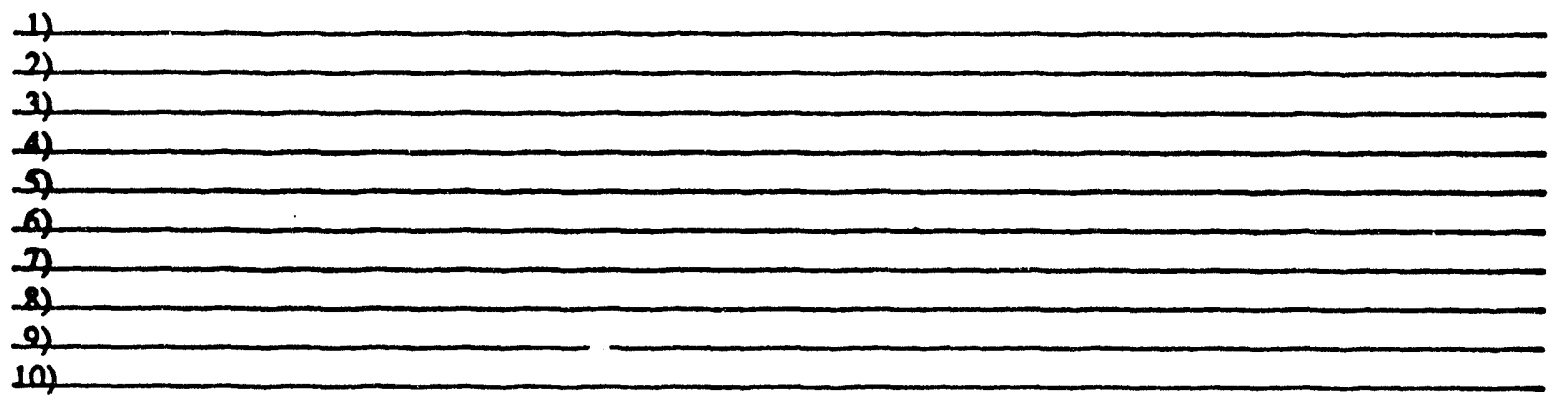

Fig. 2 (continucd) 
Biological Treatments:

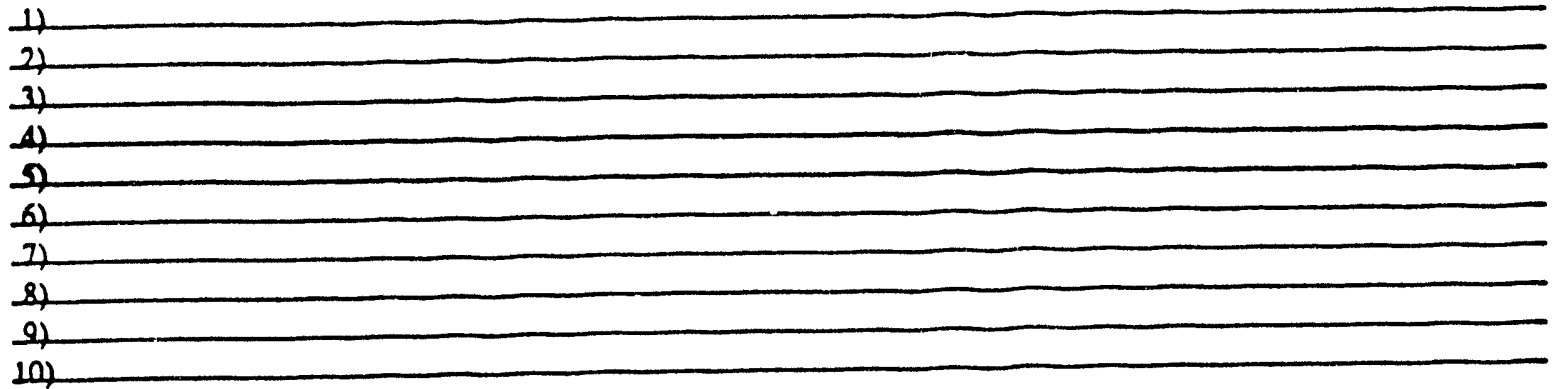

TECHNOLOGY EVALUATION RATIONAL INCORPORATING PP/NM

Treatment Evaluation Rationale:

Based on the evaluation performed, all of the physical treatment options were eliminated for the following reasons, Bhysical treatment lechnolosies (PPT) numbers I and 2 are in-situ exinction lechnologies that do not work well when the contamination is cencentraled near the surface. PPT number 3 , in in-situ immobilization lechnology. is limited by its ability to theroughly immobilize some volatile and semivolatile orpanics includine TCE. PPT number 4 was eliminaled by detailed research of reference materials which concluded that this lechnolosy was limiled by the presence of excessive fines and clays that inhibit mobility of the chemical lieatment solution throush the matrix. Finally. PPT number 5 was limited by particle size distribution of the matrix and the presence of significant quantities of roots, twips, leaves, and other decomposine material that might inhibit the soil washine. process.

Thus, with the elimination of the physical technologies, the focus is now on the thermal treatment lechnologies OTID identified previously es potentially applicable. Thermal desorption/reduction technologies jentified es IIT numbers 1 2. and 4 are effective for some volatile metals such as mercury, but will probably nor be effective for arsenic because the boiline point of this metal is in excess of the upper temperature range of thermal desorution. $1 \mathrm{is}$ determined that the high-lemperature cyclone fumace incineration treatment lechnology (TT number 3 ) is preferred for this stream. The cyclonic action provides the additional benefil of breaking apart lightly bound

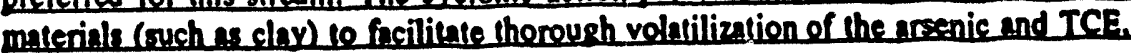

Fig. 2 (continuad) 
PPNWM Rationale:

Have any applicable treatment technologies been identified that reduce? _ Volume $X$ Toxicity _ Does Not Apply

YES NO

Have any applicable treatment technologies been identified that immobilize contaminants?

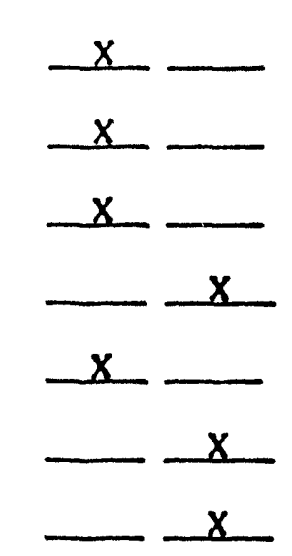

Can any primary waste stream(s) be reused or recycled after treatment?

Can any primary waste stream(s) be returned to the AOC after treatment?

Can any primary waste stream(s) be exchanged for reuse after treatment?

Can any secondary waste stream(s) be reused or recycled?

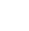

Can ariy secondary waste stream(s) be retumed to the AOC?

Can any secondary waste stream(s) be exchanged for reuse after treatment?

PPNWM Rational:

By using the cyclone fumace technology, the TCE is destroyed in the combustion chamber, and the volatilized arseaic is captured by the process. The treated soils resemble volcanic glass, which immobilizes trace quantities of any remaining metals. The vitrified material can be reused appropriately as fill material. Thus, only a small quantity of fly ash (primary soil) collected in a baghouse is produced as a secondary waste stream. Overall, toxicity was virtually eliminated, and overall volume remained fairly constant in this scenario.

Fig. 2 (continucd) 


\subsubsection{Summary Hazardous Constituen/Waste Group Table}

Identify waste groups for specific contaminants determining potentially applicable technologies based on the waste groups and media in the Example Waste Stream Information (Fig. 2). Locate the contaminants in Table 1, and identify the associated contaminant group (if not already known). Then complete Sect. 3 of the FS Project Phase Checklist (Fig. 1).

Comprehensive lists can be found in 40 CFR 268, Appendix III (FR July 1991) and the Risk Engineering Database (EPA July 1992) accessed through the Advanced Treatment Technologies Information Center (ATTIC) database (EPA May 1992).

\subsubsection{Applicable Treatment Technology Summary}

Identify the treatment technologies and correlate based on applicable contaminant and media information in the Example Waste Stream Information (Fig. 2). After identifying all known contaminants from the Summary Hazardous Constituent/Waste Group Table (Table 1), apply the information to the Summary Technology Correlation (Tables 2 through 5) to identify the technology or technologies potentially applicable to treating the contaminants and media. Then complete Sect. 3 of the FS Project Phase Checklist (Fig. 1).

Although the technology may be applicable to the project situation if the contaminants and media are indicated with the technology as being potentially applicable. The user is cautioned that this information is fairly broad in nature. Identification of a technology as potentially applicable is not to be interpreted any other way. Because most of the contaminant groups actually include many hazardous constituents, detailed research is required. Thus, treatability and feasibility studies focused on specific hazardous constituents, which simultaneously consider other technical issues during the screening processes, are needed to ensure the technology is appropriate.

Sources for technology information are too numerous to list here. The primary sources are the EPA's Superfund Innovative Technology Evaluation Program, Vendor Information System for Innovative Treatment Technologies, and ATTIC databases.

\subsubsection{Treatment Technology Evaluation Incorporating PP/WM}

Evaluate treatment technologies incorporating PP/WM in the Example Waste Stream Information (Fig. 2). Then complete Sect. 3 of the FS Project Phase Checklist (Fig. 1). 
Table 1. Summary Hazardous Constitucnt/Waste Group Table

\section{CONSTITUENT}

\section{1, 2, 4-trichlorobenzene}

1. 4-dichlorobenzene

1, 2-Dichloropropane

1, 1, 1, 1-tetrachloroethane

1, 1,1-Trichloroethane

1, 2-Trans-dichloroethene

1, 1, 2-Trichloroethane

1, 2-Dichloroethene

1, 2-bis (2-chloroethoxy) ethane

1, 1-Dichloroethene

1,2-dichlorobenzene

1, 2-diphenylhydrazine

1, 1, 2-trichloro-1, 2, 2-trifluoroethane

1,3-dichlorobenzene

1, 1-Dichloroethane

1, 2-Dichloroethane

2, 4. 5-Trichlorophenol

2, 4, 6-Trichlorophenol

2. 4-dichlorophenol

2, 6-dinitrotoluene

2, 4-dinitrotoluene

2,4-dimethyphenol

2, 4-dinitrophenol

2-buthanone

2-chloronapthalene

2-chlorophenol

2-hexanone

2-methylnapthalene

2-methylphenol

2-methynaphthalene

2-nitroaniline

3,3-dichlorobenzidine

3-nitroaniline

4, 4'-DDE

4, 6-dinitro-2-methylphenol

4, 4'-DDt

4, 4'-DDD

4-bromophenyl phenyl ether

4-chloroaniline

4-chlorophenyl phenylether

4-methyl-2-pentanone

4-methylphenol

4-nitroaniline

Acenaphthene

Acenapthylene

Acetic acid

Acelone

Acetyl chloride

Acrolein
CONTAMINANT GROUP

Halogenated Semivolatiles

Halogenated Semivolatiles

Halogenated Volatiles

Halogenated Volatiles

Halogenated Volatiles

Halogenated Volatiles

Halogenated Volatiles

Halogenated Volatiles

Halogenated Semivolatiles

Halogenated Volatiles

Halogenated Semivolatiles

Nonhalogenated Semivolatiles

Halogenated Volatiles

Halogenated Semivolatiles

Halogenated Volatiles

Halogenated Volatiles

Halogenated Semivolatiles

Halogenated Semivolatiles

Halogenated Sermivolatiles

Nonhalogenated Semivolatiles

Nonhalogenated Semivolatiles

Nonhalogenated Semivolatiles

Nonhalogenated Semivolatiles

Nonhalogenated Volatiles

Halogenated Semivolatiles

Halogenated Semivolatiles

Nonhalogenated Volatiles

Nonhalogenated Semivolatiles

Nonhalogenated Semivolatiles

Nonhalogenated Semivolatiles

Nonhalogenated Semivolatiles

Halogenated Semivolatiles

Nonhalogenated Semivolatiles

Organic Pesticides/Herbicides

Nonhalogenated Semivolatiles

Organic Pesticides/Herbicides

Organic Pesticides/Herbicides

Halogenated Semivolatiles

Halogenated Semivolatiles

Halogenated Semivolatiles

Nonhalogenated Volatiles

Nonhalogenated Semivolatiles

Nonhalogenated Semivolatiles

Nonhalogenated Semivolatiles

Nonhalogenated Semivolatiles

Organic Corrosives

Nonhalogenated Volatiles

Organic Corrosives

Nonhalogenaled Volaules 
Table 1 (continucd)

\section{CONSTITUENT}

\author{
Actylonitrile \\ Aldrin \\ Aluminum \\ Aniline \\ Anthracene \\ Antimony \\ Aromatic sulfonic acids \\ Arsenic \\ Asbestos \\ Barium \\ Barium \\ Benzene \\ Benzidine \\ Benzo (ghi) perylene \\ Benzo (b) floranthene \\ Benzo (a) anthracene \\ Benzo (a) pyrene \\ Benzo (k) floranthene \\ Benzoic acid \\ Benzyl alcohol \\ Beryllium \\ Bhc-alpha \\ Bhc-beta \\ Bhc-delta \\ Bhc-gamma \\ Bis phthalene \\ Bis (2-chloroethoxy) Phthalate \\ Bis (2-ethylhexyl) phthalate \\ Bis (2-chlorethoxy) ether \\ Bis-(2-chloroethoxy) methane \\ Bis-(2-chloroethyl) ether \\ Bis-(2-chloroisopropyl) ether \\ Bismuth \\ Bismuth \\ Bismuth \\ Bromodichloromethane \\ Bromoform \\ Bromomethane \\ Butyl benzyl phthalate \\ Cadmium \\ Calcium hydroxide \\ Calcium \\ Calcium carbonate \\ Carbon Disulfide \\ Carbon tetrachloride \\ Chlorates \\ Chlordane \\ Chlorobenzene \\ Chlorodibromomethane
}

CONTAMINANT GROUP

Nonhalogenated Volatiles

Organic Pesticides/Herbicides

Nonvolatile Metals

Organic Corrosives

Nonhalogenated Semivolatiles

Nonvolatile Metals

Organic Corrosives

Volatile Metals

Asbestos

Radioactives

Nonvolatile Metals

Nonhalogenated Volatiles

Nonhalogenated Semivolatiles

Nonhalogenated Semivolatiles

Nonhalogenated Semivolatiles

Nonhalogenated Semivolatiles

Nonhalogenated Semivolatiles

Nonhalogenated Semivolatiles

Nonhalogenated Semivolatiles

Nonhalogenated Semivolatiles

Nonvolatile Metals

Organic Pesticides/Herbicides

Organic Pesticides/Herbicides

Organic Pesticides/Herbicides

Organic Pesticides/Herbicides

Nonhalogenated Semivolatiles Halogenated Semivolatiles

Nonhalogenated Semivolatiles

Halogenated Semivolatiles

Halogenated Semivolatiles

Halogenated Semivolatiles

Halogenated Semivolatiles

Nonvolatile Metals

Nonmatallic Toxic Elements

Volatite Metals

Halogenared Volatiles

Halogenated Volatiles

Halogenated Volatiles

Nonhalogenated Semivolatiles

Nonvolatile Metals

Inorganic Corrosives

Nonvolatile Metals

Inorganic Corrosives

Nonhalogenated Volatiles

Halogenated Volatiles

Oxidizers

Organic Pesticides/Herbicides

Halogenated Volaules

Halogenated Volatiles 
Table 1 (continued)

\section{CONSTITUENT}

Chloroethane

Chloroform

Chloromethane

Chloropropane

Chromates

Chromium

Chrysene

Cis, 1, 3-dichloropropene

Cobalt

Copper

Cresols

Cresylic acid

Cyanide

Cyclohexanone

Di-n-butyl phthalate

Di-n-octyl phthalate

Dibenzfuran

Dibenzo $(a, h)$ anthracene

Dibromomethane

Dichloroethylene (DCE)

Dichloromethane

Dieldrin

Diethyl phthalate

Dimethyl phthalate

Dioxin

Endosulfan II

Endosulfan sulfate

Endosulfan I

Endrin aldehyde

Endrin

Ethion

Ethyl acetate

Ethyl ether

Ethyl parathion

Fluorene

Fluorine

- Fluorothene

Fluorotrichoromethane

Formic acid

Furan

Hadrazine

Heptachlor epoxide

Heptachlor

Hexachlorobenzene

Hexachlorobutadiene

Hexachlorocyclopentadiene

Hexaochloroethane

Hydrochioric acid

Hydronuoric acid
CONTAMINANT GROUP

Halogenated Volatiles

Halogenated Volatiles

Halogenated Volatiles

Halogenated Volatiles

Oxidizers

Nonvolatile Metals

Nonhalogenated Semivolatiles

Halogenated Volatiles

Nonvolatile Metals

Nonvolatile Metals

Nonhalogenated Semivolatiles

Organic Corrosives

Inorganic Cyanides

Nonhalogenated Volatiles

Nonhalogenated Semivolatiles

Nonhalogenated Semivolatiles

Nonhalogenated Semivolatiles

Nonhalogenated Semivolatiles

Halogenated Volatiles

Halogenated Volatiles

Halogenated Volatiles

Organic Pesticides/Herbicides

Nonhalogenated Semivolatiles

Nonhalogenated Semivolatiles

Dioxins/Furans

Organic Pesticides/Herbicides

Organic Pesticides/Herbicides

Organic Pesticides/Herbicides

Organic Pesticides/Herbicides

Organic Pesticides/Herbicides

Organic Pesticides/Herbicides

Nonhalogenated Volatiles

Nonhalogenated Volatiles

Organic Pesticides/Herbicides

Nonhalogenated Semivolatiles

Nonmetalic Toxic Elemens

Nonhalogenated Semivolatiles

Halogenated Volatiles

Organic Corrosives

Dioxins/Furans

Reducers

Organic Pesticides/Herbicides

Organic Pesticides/Herbicides

Halogenated Semivolatiles

Halogenated Semivolatiles

Halogenated Semivolatiles

Halogenated Volatiles

Inorganic Corrosives

Inorganic Comosives 
Table 1 (continued)

\section{CONSTITUENT}

Indeno (1, 2, 3-cd) pyrene

lodine

Iron

Isobutanol

Isophorone

Lead

Magnesium

Manganese

Mercury

Metalic cyanides

Methanol

Methyl isobutyl ketone

Methylene cloride

Methylparathion

n-butyl alcohol

n-nitrosodi-n-propylamine

n-nitrosodimethylamine

n-nitrosodiphenylamine

Napthalene

Nickel

Nitric acid

Nitrobenzene

Organonitriles

p-chloro-m-cresol

Parathion

PCB (Aroclor)- 1242

PCB (Aroclor)-1248

PCB (Aroclor)-12.32

PCB NOS (Not otherwise Specified)

PCB (Aroclor)-1254

PCB (Aroclor) -1260

PCB (Aroclor)-1221

PCB (Aroclor)-1016

Pentachlorophenol (PCP)

Perchloroethylene (PCE)

Phenanthrene

Phenol

Phenyl napthalene

Phosphides

Plutonium

Polycyclic aromatic hydrocarbons (PAH)

Polynuclear aromatic hydrocarbons (PNA's)

Potassium

Potassium carbonate

Pyrene

Pyridine

Radium

Radon

Selenium

\section{CONTAMINANT GROUP}

Nonhalogenated Semivolatiles

Radioactives

Nonvolatile Metals

Nonhalogenated Volatiles

Nonhalogenated Semivolaciles

Volatile Metals

Nonvolatile Metals

Nonvolatile Metals

Volatile Metals

Inorganic Cyanides

Nonhalogenated Volatiles

Nonhalogenated Volatiles

Halogenated Volatiles

Organic Pesticides/Herbicides

Nonhalogenated Volatiles

Nonhalogenated Semivolatiles

Nonhalogenated Semivolatiles

Nonhalogenated Semivolatiles

Nonhalogenated Semivolatiles

Nonvolatile Metals

Inorganic Corrosives

Nonhalogenated Semivolatiles

Organic Cyanides

Halogenated Semivolatiles

Organic Pesticides/Herbicides

PCBs

PCBs

PCBs

PCBs

PCBs

PCBs

PCBs

PCBs

Halogenated Semivolatiles

Halogenated Volatiles

Nonhulogenated Semivolatiles

Nonhalogenared Semivolatiles

Nonhalogenated Semivolatiles

Reducers

Radioactives

Nonhalogenated Semivolatiles

Polynuclear Aromatics

Nonvolatile Metals

Inorganic Corrosives

Nonhalogenated Semivolatiles

Nonhalogenated Semivolatiles

Radioactives

Radioactives

Nonvolatile Metals 
Table 1 (continued)

\section{CONSTITUENT}

Sodium

Sodium hydroxide

Solvents

Styrene

Sulfides

Sulfuric acid

Tetrachloroethene

Tetrachloroethylene

Tetrachiorophenol

Thorium

Tin

Tolvene

Total chlorinated hydrocarbons

Toxaphene

Trans-1, 3-dichloropropene

Trichloroethene

Trichloroethylene (TCE)

Trimethyl benzene

Uranium

Vanadium

Vinyl chloride

Vinyl acetate

Xylenes

Zinc

\section{CONTAMINANT GROUP}

Nonvolatile Metals Inorganic Corrosives Solvents

Nonhalogenated Volatiles

Reducers

Inorganic Corrosives

Halogenated Volatiles

Halogenated Volatiles

Halogenated Semivolatiles

Radioactives

Volatile Metals

Nonhalogenated Volatiles

Halogenated Volatiles

Organic Pesticides/Herbicides

Halogenated Volatiles

Halogenated Volatiles

Halogenated Volatiles

Nonhalogenated Volatiles

Radioactives

Nonvolatile Metals

Halogenated Volatiles

Nonhalogenated Volatiles

Nonhalogenated Volatiles

Nonvolatile Metals 
Table 2 Summary Technology Corrclation Table-Physical Trcatment

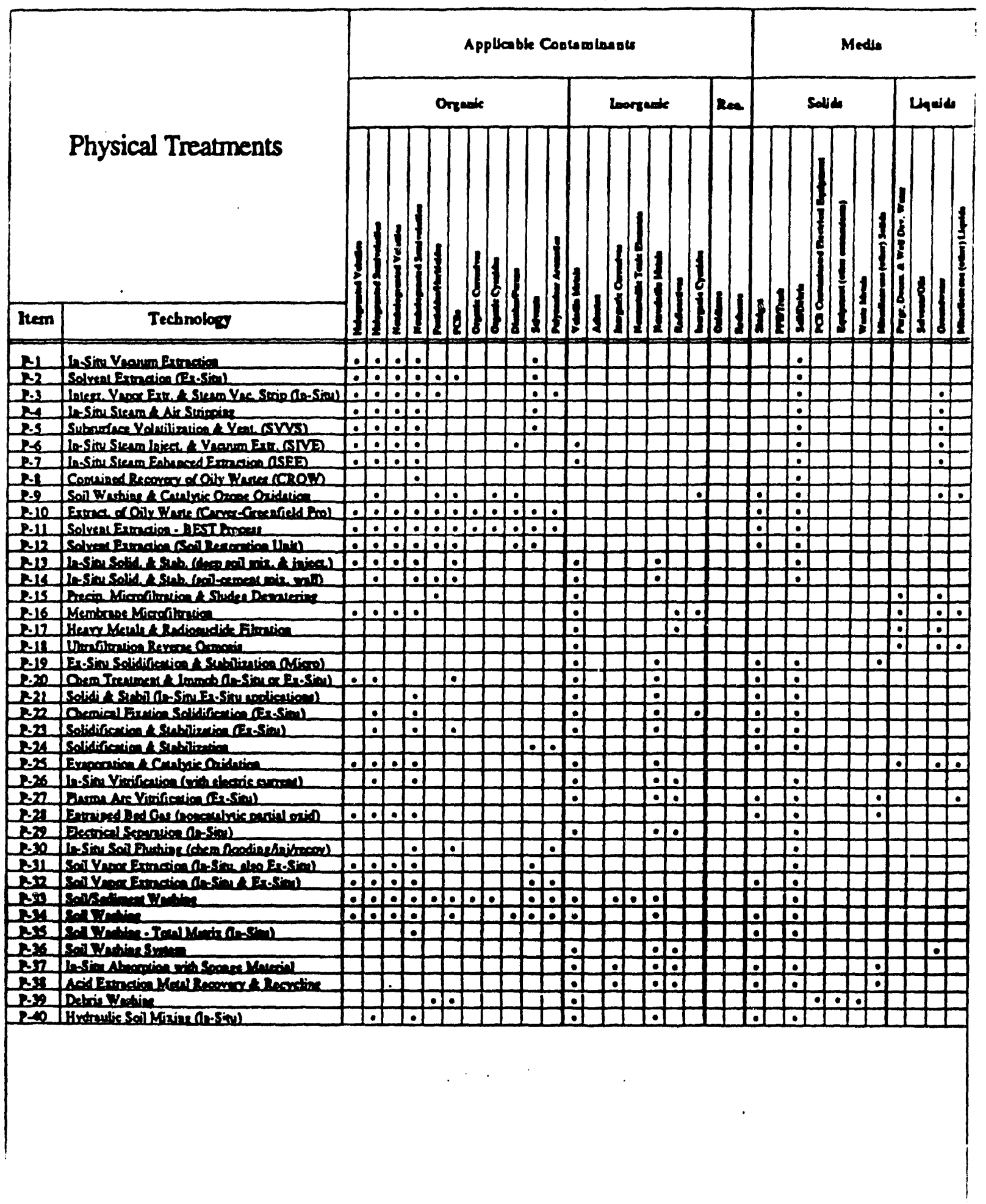


Table 3. Summary Technology Correlation Table-Chemical Trcaumcot

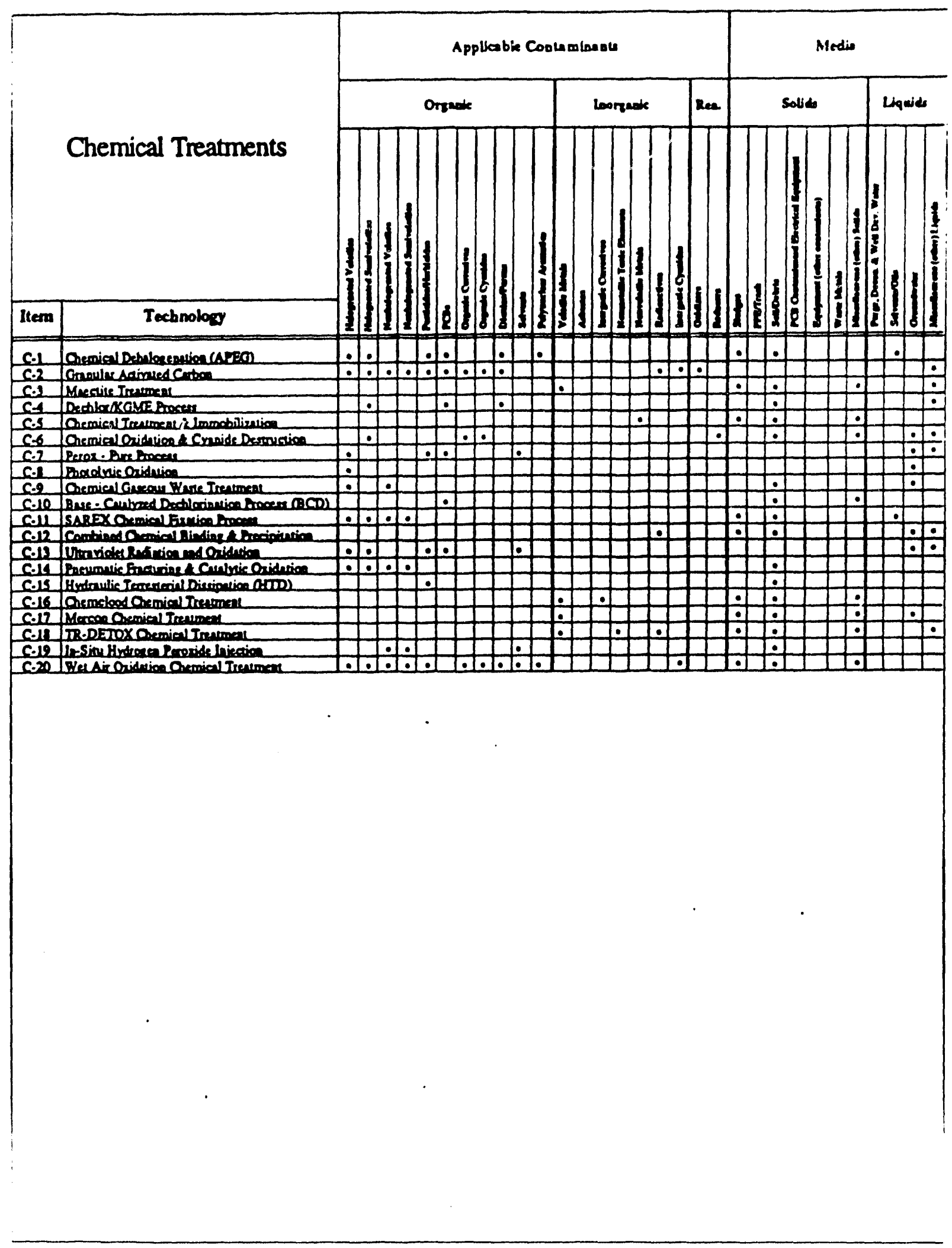


Tablc 4. Summary Technology Correlation Tablc-Thermal Treatment

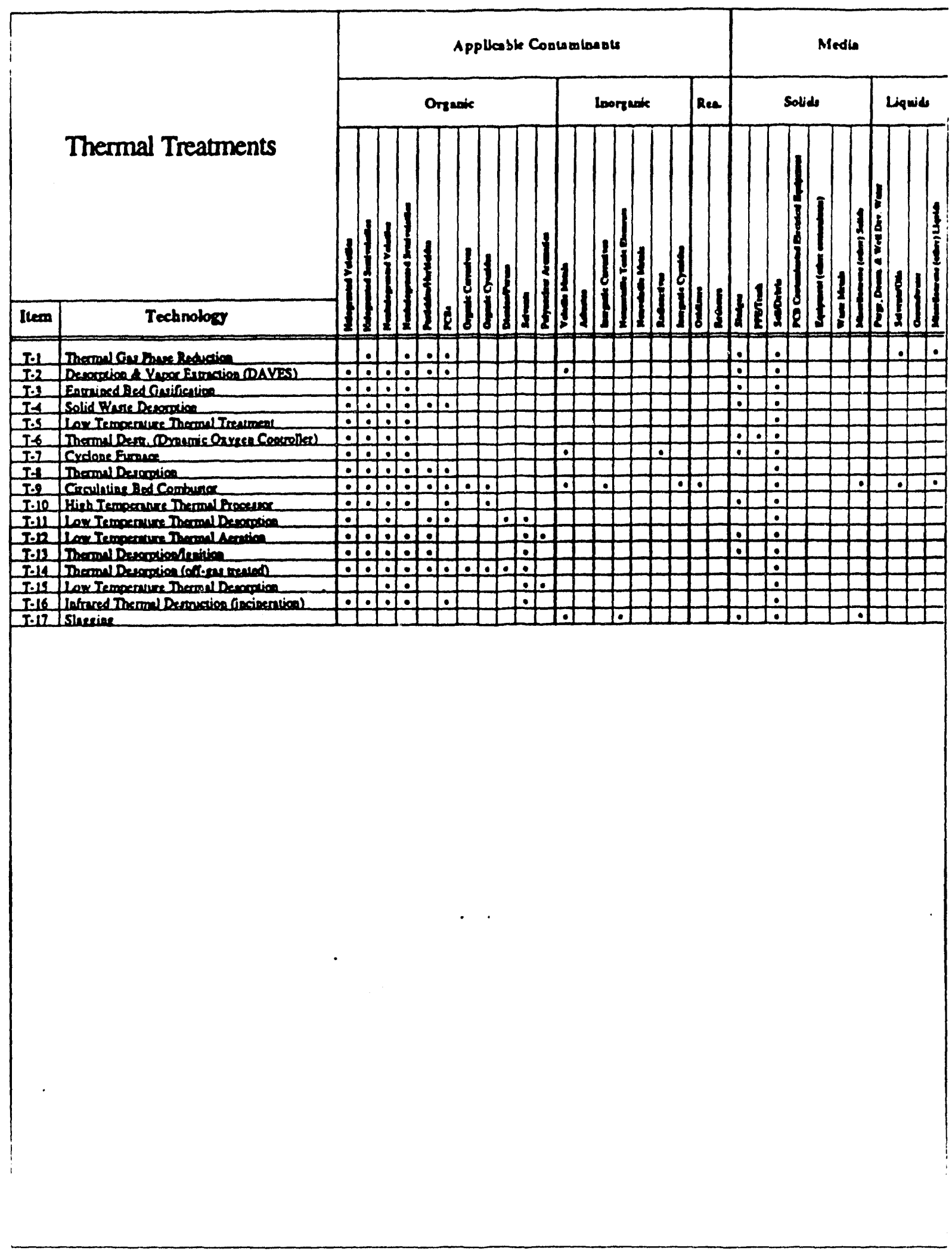


Table 5. Summary Technology Corrclation Table-Biological Treatment

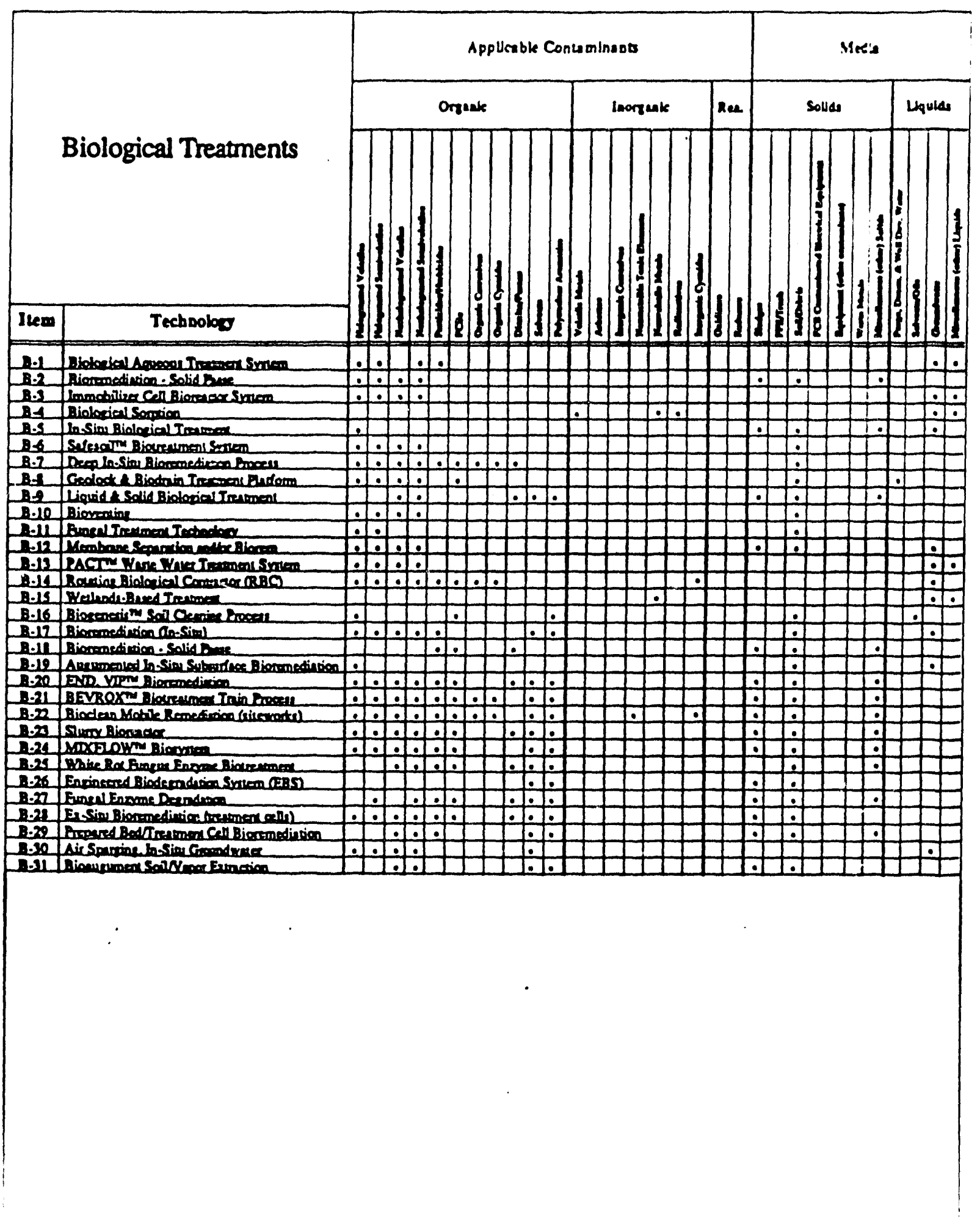




\section{BIBLIOGRAPHY}

Energy Systems (Martin Marietta Energy Systems, Inc.). 1993. Oak Ridge K-25 Site Technology Logic Diagram, Vol. 1: Technology Evaluation. K-2073, Oak Ridge K-25 Site, Oak Ridge, Tennessee, February.

Energy Systems.' 1993. Oak Ridge K-25 Site Technology Logic Diagram, Vol. 2: Technology Logic Diagrams. K-2073, Oak Ridge K-25 Site, Oak Ridge, Tennessee, February.

Energy Systems. 1993. Oak Ridge K-25 Site Technology Logic Diagram, Vol. 3, Part A: Characterization, Decontaminatiom, and Dismantlement. K-2073, Oak Ridge K-25 Site, Oak Ridge, Tennessee, February.

Energy Systems. 1993. Oak Ridge K.25 Site Technology Logic Diagram, Vol. 3, Part B: Remedial Action, Robotics/Automation, and Waste Management. K-2073, Oak Ridge K-25 Site, Oak Ridge, Tennessee, February.

Energy Systems. 1993. Decontamination and Decommissioning Technology Assessment. DOE/OR-1051, Oak Ridge K-25 Site, Technical Division, Oak Ridge Tennessee, March. 


\section{DISTRIBUTION}

1. R. O. Barnett

2. D. T. Bell

3. S. C. Bieniek

4. H. L. Boston

5. C. Clark

6. J. S. Colley

7. K. W. Cook

8. R. B. Cook

9. T. Dahl

10. D. T. Davenport

11. M. F. P. DeLozier

12. C. J. Ford

13. C. D. Goins

14. J. A. Greene

15. J. T. Grumski

16. P. J. Halsey

17. T. C. Houk

18. G. L. Johnson

19-20. A. K. Lee/DOE-OSTI

21. J. C. Massey

22-25. D. M. Matteo

26-27. P. T. Owen

28. B. E. Phifer, Jr.

29. E. J. Powell

30. A. S. Quist

31. G. E. Rymer

32. C. M. Smith

33. J. S. Suffern

34. A. E. Watzer

35. D. R. Watkins

36. R. K. White

37. Central Research Library

38-42. ER Document Management Center

43. ORNI. Laboratory Records

44-45. R. L. Nace, Branch Chief, Nonenrichment Facilities, Oak Ridge Program Division, Office of Eastern Area Programs, Office of Environmental Restoration, EM-423, Trevion 2, U.S. Department of Energy, Washington, DC 20585

46. R. C. Sleeman, DOE Oak Ridge Field Office, P.O. Box 2001, Oak Ridge, TN 37831-8541

47. D. W. Swindle, Radian Corporation, 120 South Jefferson Circle, Oak Ridge, TN 37830

48-49. H. M. Thron, Chief, Enrichment Facilities, Oak Ridge Program Division, Office of Eastern Area Programs, Office of Environmental Restoration, EM-423, Trevion 2, U.S. Department of Energy, Washington, DC 20585

50. Office of Scientific and Technical Information, P.O. Box 62, Oak Ridge, TN 37831 

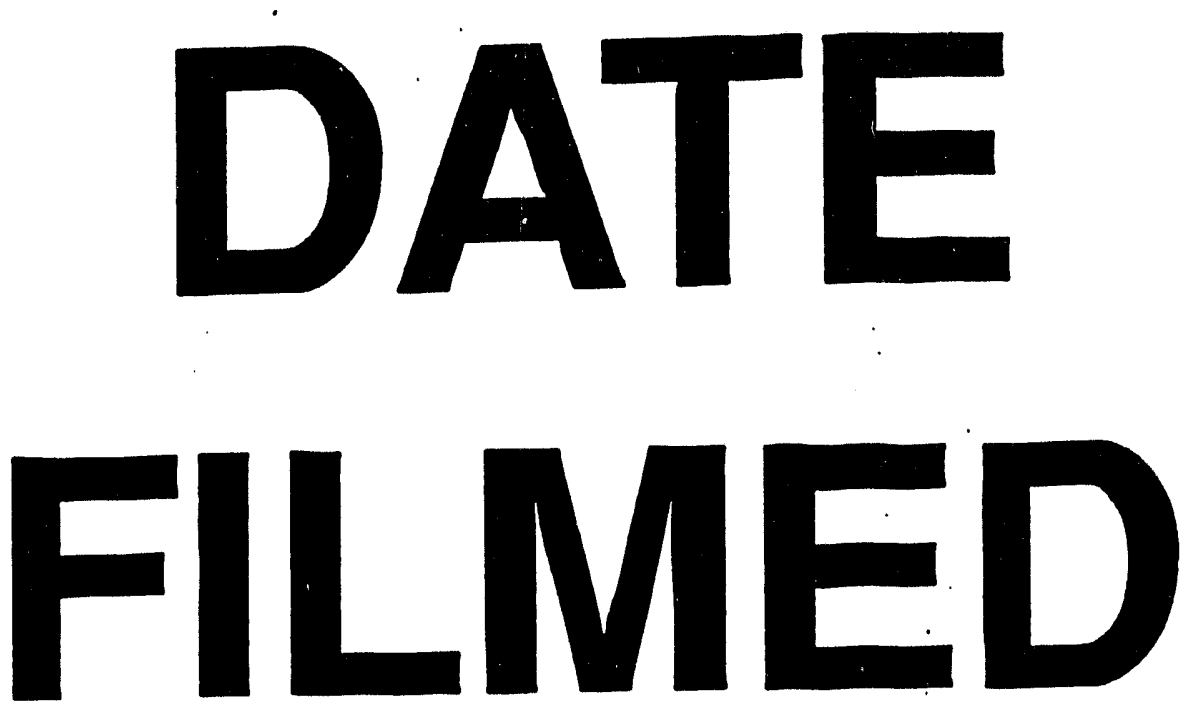

$11 / 17 / 93$
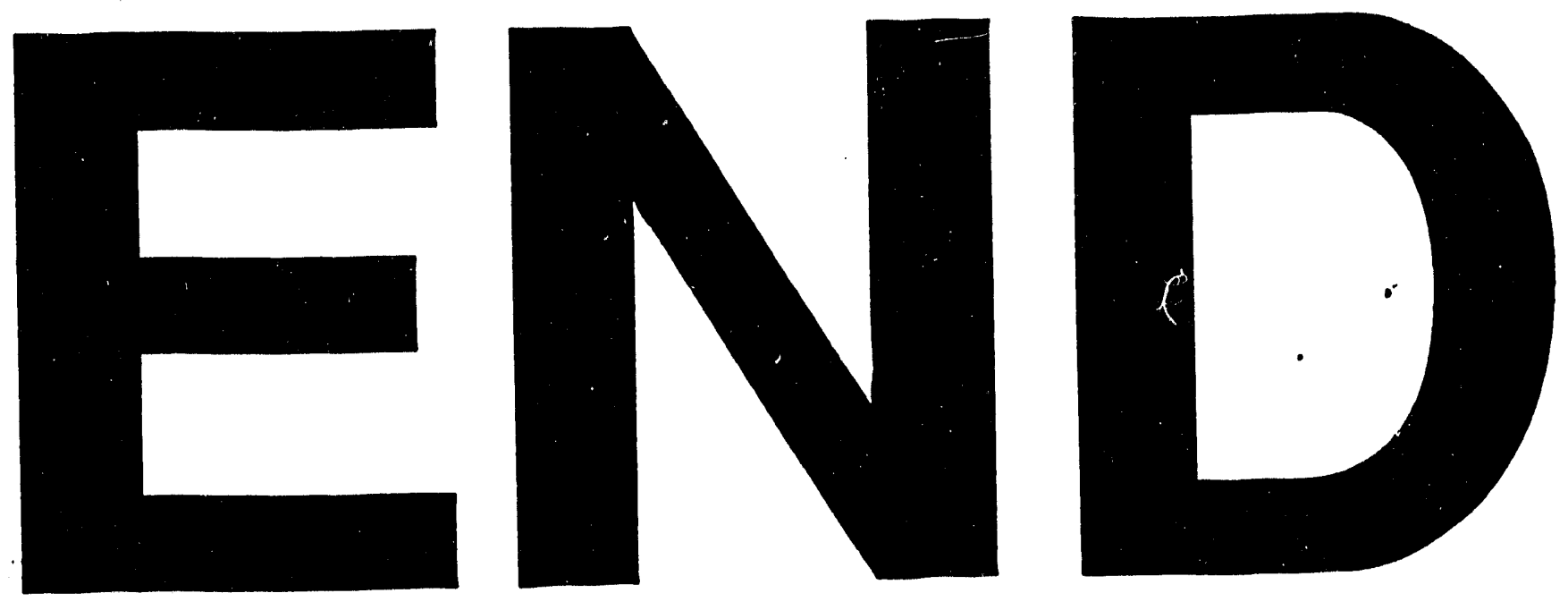


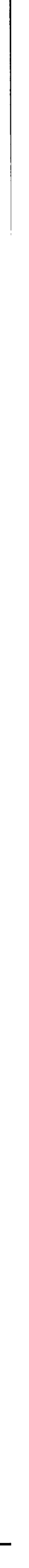

